\title{
The global water crises: a cross-national analysis of metabolic rift theory
}

\author{
Andrew Hargrove ${ }^{1}$
}

Stony Brook University, USA

\begin{abstract}
Unchecked consumption, extraction, and growth have resulted in severe damage to ecological systems. Fresh water issues constitute one of the great challenges for political ecologists. On the one hand, there is a human health and development crisis and over 700 million people still lack access to clean, safe drinking water. On the other hand, there is a growing environmental water crisis regarding water scarcity, water stress, and freshwater resource depletion. This analysis utilizes metabolic rift theory to demonstrate the disruptive consequences that human development and agriculture have on the water cycle. I use two-way fixed effects longitudinal regression for 176 nations from 1970-2015 to test how agriculture, capital, international aid, governance, and civil society are associated with two important water indicators: access to water and water stress. I find that agriculture is associated with higher levels of water stress and higher levels of water access. Higher GDP per capita and international aid increase water access but have no significant relationship with water stress. Additionally, international non-governmental organizations and environmental treaty ratifications are associated with decreased water stress, but also decreased water access. Therefore, I find that the disruptive processes of capital and development have differential impacts on these two interrelated water outcomes. This political ecological analysis suggests that simple solutions that address water access or water stress alone, without considering the interrelated aspects of global water issues, may inadvertently influence other facets of the world's growing water concerns. Furthermore, agriculture and development create an ever-growing metabolic rift in the processes that allow fresh water to replenish itself, leading to future global issues of water access and stress.
\end{abstract}

Keywords: metabolic rift, water access, water stress, international aid, agriculture, development

\section{Résumé}

La consommation, l'extraction et la croissance économique incontrôlées ont endommagé les systèmes écologiques. L'accès à l'eau douce est un défi majeur. Plus de 700 millions de personnes n'ont toujours pas accès à une eau potable propre et salubre. Il existe également une crise de pénurie d'eau, un stress hydrique et un épuisement des ressources en eau douce. Cette analyse utilise la théorie du rift métabolique pour démontrer les perturbations que le développement humain et l'agriculture provoquent pour le cycle de l'eau. J'utilise une régression longitudinale à effets fixes bidirectionnelle pour 176 pays de 1970 à 2015 pour tester comment l'agriculture, le capital, l'aide internationale, la gouvernance et la société civile sont associés à deux indicateurs importants de l'eau : l'accès à l'eau et le stress hydrique. Je trouve que les sociétés agricoles sont associées à des niveaux plus élevés de stress hydrique et à un meilleur accès à l'eau. Un PIB par habitant plus élevé et plus d'aide internationale augmentent l'accès à l'eau, mais n'ont pas de relation significative avec le stress hydrique. De plus, les ratifications des ONG internationales et des traités environnementaux sont associées à une diminution du stress hydrique, mais également à une diminution de l'accès à l'eau. Par conséquent, je trouve qu'un meilleur accès au capital et plus de développement ont des impacts différentiels sur le stress hydrique et l'accès. Cette analyse «political ecology» suggère que des solutions simples qui traitent uniquement de l'accès à l'eau ou du stress hydrique peuvent aggraver par inadvertance les problèmes d'eau. De plus, l'agriculture et le

\footnotetext{
${ }^{1}$ Andrew Hargrove is currently an instructor in the Judy Genshaft Honors College at the University of South Florida, USA and completing PhD student in Sociology at Stony Brook University, USA. Email: awhargrove "at" usf.edu. I would like to thank the JPE editor, Prof. Casey Walsh, and the anonymous reviewers for their constructive comments and feedback. I am grateful to Rebekah Burroway and Jamie M. Sommer for their assistance and recommendations. Funded by an NSF Graduate Research Fellowship. All errors remain my own.
} 
développement créent une faille métabolique de plus en plus grande dans les processus qui permettent à l'eau douce de se reconstituer, entraînant de futures crises d'accès à l'eau et de stress hydrique.

Mots clés: rift métabolique, accès à l'eau, stress hydrique, aide internationale, agriculture, développement

\section{Resumen}

El consumo sin control, la extracción y el desarrollo, han resultado en un grave daño a los sistemas ecológicos. Los problemas relacionados con el agua dulce constituyen uno de los grandes retos de la ecología política. Por un lado, existe una crisis de salud humana y de desarrollo en la que 700 millones de personas aún carecen de acceso a agua limpia y potable. Por otro lado, hay una creciente crisis ambiental de agua relacionada con la escasez y el agotamiento hídricos. Este análisis utiliza la teoría de la brecha metabólica para demostrar las perturbadoras consecuencias que el desarrollo humano y la agricultura tienen sobre el ciclo del agua. Aquí utilizo regresión longitudinal de dos vías con efectos fijos para 176 naciones, entre 1970 y 2015, para probar cómo la agricultura, el capital, la asistencia internacional, la gobernanza y la sociedad civil, están asociadas con dos importantes indicadores del agua: acceso a esta y su escasez. Encuentro que la agricultura está asociada con mayores niveles de escasez y altos niveles de acceso al agua. El producto interno bruto per cápita, así como el aumento de la asistencia internacional, incrementan el acceso al agua, pero no tienen una relación considerable con la escasez hídrica. Además, las organizaciones internacionales no gubernamentales y las ratificaciones de tratados internacionales están asociadas con la reducción de la escasez del agua, pero también con la reducción en el acceso. Por tanto, encuentro que los procesos disruptivos del capital y el desarrollo, tienen efectos diferenciados en estas dos consecuencias que se encuentran interrelacionadas en temas de agua. Con base en perspectivas de ecología política, este análisis sugiere que soluciones simples que abordan acceso al agua o su escasez solamente, sin considerar los aspectos interrelacionados de temas hídricos globales, pueden causar daño de manera inadvertida a otros aspectos de la creciente preocupación mundial sobre el agua. Más aún, la agricultura y el desarrollo producen una creciente brecha metabólica en el proceso que permite al agua dulce reabastecerse, provocando futuros problemas mundiales de acceso y escasez.

Palabras clave: brecha metabólica, acceso al agua, escasez de agua, asistencia internacional, agricultura, desarrollo

\section{Introduction}

Water issues are some of the world's most pressing problems. The World Economic Forum has ranked water issues among the top five global risks for the past nine years (World Economic Forum, 2020). Currently, there are at least two separate, but concurrent water crises: a human health and development water crisis concerning populations who lack access to clean, safe drinking water and an environmental water crisis regarding freshwater scarcity, water stress, and freshwater resource depletion (Barlow, 2014; Hargrove, 2019; Bernabé-Crespo et al., 2019). These complex large-scale events threaten the social, economic, and ecological systems that underpin our species' existence (Galaz et al., 2011; Homer-Dixon et al., 2015). In the capitalist economy over-withdrawal of water resources for agriculture (70\% of global withdrawals) and manufacturing (19\% of global withdrawals) has disrupted the natural water cycle, creating water stress and less access to water (Aquastat, 2020). At the global scale, we are currently extracting groundwater at rates far surpassing the speed of replenishment, and over-withdrawing surface water to such a degree that many rivers and lakes are shrinking or drying completely (Barlow, 2014; Black and King, 2009). These processes lead to increased water stress and an unsustainable future. Over 700 million people lack access to an improved water source, disproportionately affecting women and children in poor rural areas and crowded urban slums (WHO, 2016). While development and capital flows have helped to increase levels of water access over the last three decades, the disruption of the water cycle through over-withdrawal will make connecting the remaining populations to water sources and maintaining current levels of access increasingly difficult (Mekonnen and Hoekstra, 2011).

Water access, water stress, and sustainability are overlapping issues, creating multifaceted problems for nations, including widespread disease, drought, flood, famine, environmental damage, ecological disasters, and political instability (Bryant and Bailey, 1997; Shiva, 2002; Taylor and Sonnenfeld, 2017; Trainer, 2019). Current solutions to these water crises ranging from global governance initiatives (international environmental treaties and the UN establishing water as a human right) and national policies (policies on privatization, framework laws on water, and legislation to protect water resources for future generations) to international 
development (billions of dollars of aid to the water sector and research on water solutions) do not adequately address the complex interrelated nature of water issues and make little effort to reduce the disruption that agriculture and development cause in the water cycle (Ahlborg and Nightingale, 2018; Hargrove, 2019). Drawing on human ecology perspectives, future solutions to these separate but connected problems of water access and water stress must aim to reduce disruption to the water cycle to allow for a sustainable future for both human society and the environment (Paulson and Gezon, 2005; Peet and Watts, 2004; Healy, 2019).

Following Metabolic Rift Theory, processes connected to economic and technological development extract more from ecological resources than they return to the source. This disconnect between nature and society creates a rift in the balance or metabolism of our world, resulting in a natural resource becoming more and more degraded and depleted the longer these human processes continue (Foster, 1999). The High Plains Aquifer in the midwestern United States is a clear example of this process, as ever greater withdrawals from the aquifer to create the "breadbasket of the world" has led to depletion rates up to 24 times the annual recharge rate (Sanderson and Frey, 2014). As we develop technology to improve water access and distribution, we often withdraw more water than can be replaced through the hydrological cycle, creating a rift in the metabolism between nature and society.

In this analysis, I extend Metabolic Rift Theory to the water cycle by focusing on two important global water issues: access to water and water stress. Previous metabolic rift analyses utilize qualitative methods to highlight how the drive for capital has led to metabolic rifts in various natural processes. However, very few authors have used quantitative data, and none have taken a cross-national comparative approach. In addition, only one analysis has demonstrated a metabolic rift in the freshwater cycle (Sanderson and Frey, 2014). The water cycle, when unaffected by human intervention functions to completely recycle all water resources. However, the mass withdrawal of water from surface water (lakes and rivers) and groundwater (aquifers) has caused a rift whereby fresh water is becoming scarcer and water stress is a problem for 2.67 billion people for at least one month a year (Hoekstra et al., 2012). I use Metabolic Rift Theory to frame the current water crises in terms of a rift in the natural metabolism of the water cycle. I test the determinants of access to water and water stress using two-way fixed effects longitudinal regression with robust standard errors for 176 nations from 1970-2015. Specifically, I examine how agriculture, capital, international aid, governance, and civil society are associated with access to water and water stress. The findings show that agriculture, processes related to international development, and even past solutions to the water crises have differential impacts on water access and water stress. This suggests that solutions to these two water issues, when not confronted concomitantly, may unintentionally further extend the rift in the water cycle.

\section{Two water crises}

The global water crisis is a complex and multifaceted problem that impacts the entire global population. While global water issues encompass far more than just two problems, I see two major themes in the narratives surrounding the current water debate: a theme of human health and development and a theme of environmental degradation and scarcity. The first theme stresses that nearly $10 \%$ of the global population still lacks access to an improved water source, often walking long distances under dangerous circumstances to carry far too little water to sustain their family to their homes every day. Lack of access to an improved water source leads to millions of deaths per year, increased prevalence of water borne diseases, girls missing school daily to collect water for their family, and an overall poor quality of life for entire communities (WHO, 2016; United Nations, 2010). While great strides in connecting populations to water sources were made over the past 30 years, especially during the era of the Millennium Development Goals (MDGs), the remaining $10 \%$ of the population will be the most difficult to connect. These populations reside in rural communities and urban slums in lowand middle-income nations with less resources to pay for and construct the infrastructure needed for improved access to water sources. Additionally, many of these populations live where fresh water is scarce, for example in arid climates.

The theme of degradation and scarcity emerges from studies reporting on water stress from droughts, floods, aquifer depletion, and accelerated desiccation of rivers and lakes. Global freshwater resources are being taxed to their limit by agriculture (70\% of all withdrawals) and manufacturing (19\% of withdrawals) (Aquastat, 
2020). Agriculture utilizes over two-thirds of all water withdrawals globally, often using inefficient irrigation techniques to attain the highest possible yield and profit (Postel, 2000). The international trade of goods and services (vis-à-vis manufacturing) removes water that would be renewed through the hydrological cycle, and the global shipment of water disturbs the ecological balance of watersheds, leading to desertification, biodiversity loss, and desiccation of streams, rivers, and lakes (Barlow, 2014; Black and King, 2009). The increasing demands being placed on freshwater resources threaten the supply of water for food production, drinking, bathing, and other basic human needs (Pimentel et al., 2004; Pande and Pandit, 2018). Mekonnen and Hoekstra (2011) estimate that two-thirds of the global population already lives with severe water scarcity at least one month out of every year, and half a billion people experience it for over six months of the year. These numbers will only increase as withdrawals continue to rise and desertification processes makes water storage and replenishment increasingly difficult.

In efforts to address the many water related issues, the global community has spent billions of dollars in water supply aid (AidData, 2017; Jorgenson, 2016). International water aid accelerated rapidly following the MDGs and has invested in thousands of water initiatives globally (AidData, 2017). In addition, global governance initiatives, through international treaties, have implemented water access and water conservation policies. In 2010, the United Nations declared the right to water for basic needs a human right. These initiatives should have a positive impact on the multifaceted water crisis, however, without evaluation of these solutions it is impossible to assess whether they are extending or healing the metabolic rift in the water cycle.

\section{The theory of metabolic rift}

Metabolic Rift Theory stems from a Marxist understanding of the metabolic relationship between society (through the drive for capital) and nature (Foster, 1999). In Metabolic Rift Theory, the human environmental metabolism is a system of chemical and resource inputs and outputs. When the inputs and outputs are balanced, the human environmental metabolism is functioning. However, when an imbalance occurs through resource extraction without replenishment, a rift is created (Foster, 1999). Identifying these unequal exchanges and rifts in resource metabolisms help unveil the power imbalances that underlie human ecological interactions (Jorgenson, 2016; Hornborg and Martinez-Alier, 2016; Manzano et al., 2016). Foster (1999) argues this theory of Metabolic Rift should be applied broadly, for example guiding work in human ecology and environmental sociology.

Metabolic Rift Theory has been used to uncover and examine rifts in several human ecological relationships. York, Rosa, and Dietz (2003) explore metabolic rift theory with greenhouse gas emissions, finding that urbanization and industrialization increase emissions. Clark and York (2005) use it to examine the rift in the carbon cycle, finding that technological improvements in efficiency increase the amount of resources used, widening the rift instead of healing it. Clausen (2007) applies the theory to modern Cuban agricultural reform as a possible solution to begin to heal the rift in soil degradation through crop diversification, rotation, and community and urban farming. McMichael (2008) discusses agrofuels and biofuels, finding that replacing fossil fuels will exacerbate, not solve, the metabolic rift because palm plantations replace rainforests, savannas, and grass covered areas, leading to greater carbon dioxide emissions from the removal of these sinks while decreasing food security. Further, Clark and Foster (2009) find that through ecologically unequal exchanges, imperialist nations can maintain an ecological overdraft, furthering the metabolic rift and creating debt-laden economies both economically and ecologically. These themes also emerge in Mayer and Haas (2016) and Warlenius (2016). Additional analyses and refinements of the theory by McClintock (2010), Salleh (2010), Schneider and McMichael (2010), and Moglia (2014) extend the rift analogy to agrarian resistance, labor practices, and other agricultural issues.

\section{Metabolic rift and water}

Several researchers have applied the theory of metabolic rift to water. First, Clausen and Clark (2005) studied the metabolic relationship between society and oceans via aquaculture and marine farming. They find that the expansion of capitalist enterprise into oceans resulted in the depletion of fish stocks at multiple trophic levels, and the unbalancing of the marine ecological cycle. Aquaculture has emerged as a capitalist solution 
but has failed to resolve the metabolic rift between society and the seas, actually accelerating marine life extraction and utilizing more oil and gas resources (Clausen and Clark, 2005). Perdikaris and Paschos (2011) support this analysis, showing how aquaculture and fisheries may present a metabolic rift that may not be possible to repair.

Turning to fresh water, Sanderson and Frey (2014) focus more on the water cycle in the High Plains Aquifer, finding that capitalist needs for production, economic value, and the drive to develop agriculture in what was once a desert has created a rift in the water cycle. Though their analysis is a case study of one aquifer, it points to some of the mechanisms that drive the ecological rift in the water cycle globally, including overwithdrawal and industrial agriculture. In a further study, Hof and Blazquez-Salom (2015) perform several indepth analyses of water consumption and land use patterns for several urban-tourist forms in Mallorca. They find that tourism development, driven by capital accumulation, has resulted in an unequal socio-spatial urban landscape of water consumption. In these cases, tourism development has worsened constraints on water supply and expanded the rift between continual economic growth and finite natural resources. Finally, McGee and Alvarez (2016) use fixed effects panel regression to show the negative effects of organic agriculture on organic water pollution. They find that US states that use organic farming may actually increase organic water pollution when compared to non-organic farming practices. This is through certification and the use of natural fertilizers, which further expand the rift they are intended to heal.

I build on this research by extending Metabolic Rift to the global freshwater crisis, in order to

1) understand how human interactions with fresh water sources generate change in water access and water stress,

2) examine how solutions to the water crisis may have differing and unintended consequences on related water issues, and

3) reveal the ecological consequences of ongoing capitalist and international development processes in relation to our freshwater resources.

Controlling the flow and availability of water has been a preoccupation of society since the foundation of our first civilizations. However, advances in technology and the drive for capital during and following the Industrial Revolution gave humanity the ability to access much larger quantities of water at an accelerating rate. Dams, boreholes, running tap water, municipal water systems, and new agricultural techniques have vastly improved our quality of life. However, the growth, development, and drive for capital leading to our improved quality of life has not considered the ecological costs of accelerating water withdrawals. This acceleration is causing a growing rift in the water cycle.

Fresh water consumption through the drive for capital accumulation has also led to severe environmental health issues. Several major rivers now run dry during all or part of the dry season including the Ganges, the Nile, the Colorado, and the Yellow River (Postel, 2000). The Aral Sea, the once fourth largest lake has shrunk to $10 \%$ of its previous size. Aquifers, many of which are non-renewable, are over-tapped and withdrawals far exceed recharge rates. In addition, dams, river rerouting, and desertification has destroyed millions of acres of ecosystems and threatened the existence of many species (Black and King, 2009). These processes demonstrate a strain on the sustainability of the world's freshwater resources that indicate that the human-ecological metabolism with the water system has a serious rift, whereby human actions are causing strain on the naturally renewable water cycle. Furthermore, due to growing population pressures, increased water needs for agriculture, and the drive for capital accumulation, domestic and industrial water withdrawals will rise rapidly in the next 30 years. These increases will lead to ever more severe water stress and may result in international conflict over scarce water (Shiva, 2002).

Agriculture accounts for over two-thirds of the global blue water footprint (Hoekstra et al., 2012). Advances in agricultural technology and the drive to generate more profits have led to unsustainable farming practices. The legacy of the Green Revolution, developed as a solution to global hunger problems in the 1950s and 1960s, greatly increased the water needs necessary to germinate high-yield genetically modified seeds 
necessary to grow wheat and soybeans, among other crops (Black and King, 2009). Black and King assert that a third of mature crops are wasted every year (Black and King, 2009). The abstraction of non-renewable groundwater has enabled society to turn deserts into cropland, but at unsustainable rates (Sanderson and Frey, 2014). Water use is unavoidable, but food waste, water inefficient irrigation methods, and monocropping exacerbate the strain on global water resources (Black and King, 2009; Hargrove, 2019). Due to these pressures, I expect that greater levels of agriculture as a percentage of total land area in a nation should be associated with increased water stress and lower levels of water access.

After agriculture, manufacturing is the second largest strain on global fresh water resources. The drive to produce and consume goods, many of which are discretionary, leads to large-scale water extraction (Aquastat, 2020). Heavy users of water for industry include paper, metal, and electronics manufacturing, all of which require high quality treated water for their products. For example, the minimum amount of water required to produce $1 \mathrm{~kg}$ of paper is 324 liters (Black and King, 2009). Another heavy user of water is the water bottling industry, which extracts unsustainable amounts of water from rivers, lakes, and aquifers and shipping some of it around the globe (Black and King, 2009; Pacheco-Vega, 2019). Manufacturing and the drive for capital have led to the ever-increasing rift as withdrawals of water accelerate past replenishment rates. Therefore, I expect manufacturing, GDP per capita, and international trade should increase water stress and decrease water access.

Although industrialization and capital accumulation have created an ever-growing metabolic rift, there have been efforts to solve, or at least mitigate, water access and water stress. One of these possible solutions is international aid. Can international aid to the water sector decrease water stress and connect all populations to a water source in a sustainable manner to begin healing the metabolic water rift? Hargrove (2019) finds in an analysis of over 42,000 international water aid projects that aid has focused heavily on human development goals like education, access, and health (98\% of all water aid addresses these issues) and that far fewer aid projects have an environmental or sustainability goal (29\% of projects have an environmental component). The analysis also finds that water aid's purpose may be more focused on international relations and posturing than on solving water issues (Hargrove, 2019). Furthermore, water aid is fragmented and piecemeal, possibly leading to inefficiency and ineffectiveness. Given the above, I expect that aid may be successful at connecting populations to water sources, but it may not be addressing underlying sustainability issues. I hypothesize that international aid will be associated with increased access to water, but not decreased water stress.

Global governance via international environmental treaties include many proposed, signed, and ratified through the United Nations. Environmental treaties are non-binding contracts, but they are internationally recognized signposts to the intentions of signatory nations (Hargrove et al., 2019). Environmental treaties are associated with several important positive environmental outcomes in ratified nations including, but not limited to, reductions in $\mathrm{CO}_{2}$ emissions (Hargrove et al., 2019) and decreases in deforestation (Sommer, 2020). Many environmental treaties focus on water access and water stress/scarcity. I hypothesize that nations who have ratified more international environmental treaties should see an increase in water access and a decrease in water stress.

My analysis quantitatively tests the relationship of agriculture as a percentage of total land area, capital, international development aid, and global governance on water access and water stress. Water stress represents the toll that economic and social processes have had on the water metabolism, and access to water provides for human water needs within current available resources. Any processes that have contradictory effects on water stress and water access (greater stress and more access, or less stress and less access) will continue to exacerbate the ecological rift. These contradictory effects also demonstrate that current water solutions do not consider water issues holistically, failing to consider the multifaceted nature of environmental and human water needs. This analysis will shed light on the ecological rift in the water cycle and the processes that increase access and decrease water stress.

The first goal of the analysis is to determine the extent of changes in water access and water stress based on our human interactions by testing the impact of agriculture, economic development, manufacturing, and population on access and stress. The second goal is to examine how these human interventions have differential 
impacts on our ability to access fresh water and the stress we put on the metabolism of the water cycle. Finally, to reveal the ecological consequences of ongoing international development processes in relation to our freshwater resources. Together, the longitudinal cross-national quantitative analysis will provide evidence for some of the human processes that lead to detrimental environmental outcomes, vis-à-vis water stress.

\section{Methods}

\section{Statistical models}

I conduct cross-national time-series analyses using two-way fixed effects regression to assess the determinants of improved water development for human health (access to improved water sources, Table 1) and improved water development for environmental health (national levels of water stress). The access to improved water sources models uses robust standard errors clustered by country for 172 countries from 19902015. The water stress models use robust standard errors clustered by country for 159 countries from 19602015. Robustness checks, utilizing identical samples for the two dependent variables, yield substantively similar results. However full unbalanced models are reported here to allow for the inclusion of all relevant data. I use two-way fixed effects regression following previous cross-national analyses. Two-way fixed effects describes a stringent and statistically conservative longitudinal modeling technique that controls for both timeinvariant and unobserved factors. It allows for comparisons within countries over time, showing the direct effect in changes in the independent variables on the outcomes of interest. In addition, fixed effects with robust standard errors decreases the probability of committing a type I error, in which we erroneously find a statistically significant result where none truly exist ${ }^{2}$.

To ensure the reliability and robustness of the models, I check for various regression assumptions. All models present no potential issues with multicollinearity, influential cases, and outliers. A bivariate correlation matrix and variance inflation factor scores for the models indicate that there are no issues with multicollinearity. Standardized residuals indicate no potential issues with outliers. In addition, to ensure that there were no issues with specification error or omitted variable bias, robustness checks were run with a range of model specifications. Results for the main independent variables remained consistent regardless of various specifications. Among other things, robustness checks included controls for total population, arable land, several measures of GDP, and various measures of education. All models yield consistent results.

\section{Dependent variables}

Access to improved water source. Access to improved water source measures the percent of a nation's population connected to an improved water source. Data are available from the Aquastat (2020) database for years 1990-2015. Following the World Health Organization (2016), improved water sources are household connections, boreholes, protected springs, public standpipes, protected dug wells, and rainwater collection.

Water stress. Water stress data are measured as total water withdrawals in a nation as a percent of total renewable freshwater resources (Aquastat, 2020). This variable assesses the degree to which human consumption taxes the environment and interferes with the efficiency of the natural water cycle. Water stress is logged to deal with the skewed distribution.

\footnotetext{
${ }^{2}$ Generalized least squares random effects regression was also considered for this analysis, but due to results from a Hausman test and for the theoretical reasons discussed above, only fixed effects results are reported here. However, the results from the generalized least squares random effects regression yield substantively similar results to those reported here.
} 


\begin{tabular}{|c|c|c|c|}
\hline Variables & Description (Source) & $\begin{array}{l}\text { Mean (Std. } \\
\text { Dev.) }\end{array}$ & Range \\
\hline \multicolumn{4}{|l|}{ Dependent Variables } \\
\hline Water access & $\begin{array}{l}\text { Percent of total population with access to } \\
\text { improved water source (Aquastat, 2020) }\end{array}$ & $\begin{array}{l}84.504 \\
(17.87)\end{array}$ & $21.1-100$ \\
\hline Water stress $(\ln )$ & $\begin{array}{l}\text { Total freshwater withdrawals as a percent of } \\
\text { renewable freshwater resources (Aquastat, } \\
\text { 2020) }\end{array}$ & $\begin{array}{l}56.99 \\
(210.33)\end{array}$ & $.01-2610$ \\
\hline \multicolumn{4}{|l|}{ Independent Variables } \\
\hline $\begin{array}{l}\text { Water sector aid count } \\
\text { (stock) }\end{array}$ & $\begin{array}{l}\text { Cumulative number of projects a nation } \\
\text { received in the water sector up to each specified } \\
\text { year (AidData, 2017; Hargrove, 2019) }\end{array}$ & $\begin{array}{l}42.32 \\
(115.17)\end{array}$ & $0-1007$ \\
\hline $\begin{array}{l}\text { Water sector aid in US\$ } \\
\text { (stock) }\end{array}$ & $\begin{array}{l}\text { Cumulative value in hundred millions USD in } \\
\text { aid received in the water sector up to each } \\
\text { specified year (AidData, 2017; Hargrove, } \\
\text { 2019) }\end{array}$ & $\begin{array}{l}711.31 \\
(2188.22)\end{array}$ & $0-26400.7$ \\
\hline $\begin{array}{l}\text { Water sector aid human } \\
\text { projects (stock) }\end{array}$ & $\begin{array}{l}\text { Cumulative number of projects a nation } \\
\text { received in the water sector with a focus on } \\
\text { human needs up to each specified year } \\
\text { (AidData, 2017; Hargrove, 2019) }\end{array}$ & $\begin{array}{l}41.36 \\
(112.91)\end{array}$ & $0-979$ \\
\hline $\begin{array}{l}\text { Water sector aid } \\
\text { environmental projects } \\
\text { (stock) }\end{array}$ & $\begin{array}{l}\text { Cumulative number of projects a nation } \\
\text { received in the water sector with a focus on } \\
\text { environmental needs up to each specified year } \\
\text { (AidData, 2017; Hargrove, 2019) }\end{array}$ & $13.17(33.75)$ & $0-430$ \\
\hline $\begin{array}{l}\text { Gross domestic product } \\
\text { per capita (natural log) }\end{array}$ & $\begin{array}{l}\text { The sum of gross value added by all resident } \\
\text { producers in the economy plus any product } \\
\text { taxes and minus any subsidies not included in } \\
\text { the value of the products (World Bank, 2019) }\end{array}$ & $\begin{array}{l}7241.31 \\
(14817.43)\end{array}$ & $0-170453$ \\
\hline $\begin{array}{l}\text { Secondary female } \\
\text { education }\end{array}$ & $\begin{array}{l}\text { Percentage of students enrolled in secondary } \\
\text { education who are female (World Bank, 2019) }\end{array}$ & $45.25(8.38)$ & $0-70.45$ \\
\hline Agriculture & $\begin{array}{l}\text { Land used for agriculture (\% of total land area) } \\
\text { (World Bank, 2019) }\end{array}$ & $17.74(15.51)$ & $.04-66.67$ \\
\hline INGOs & $\begin{array}{l}\text { Number of international non-governmental } \\
\text { organizations a nation has at least one citizen } \\
\text { member in (Smith and Wiest, 2005) }\end{array}$ & $\begin{array}{l}559.69 \\
(748.92)\end{array}$ & $0-4339$ \\
\hline Environmental treaties & $\begin{array}{l}\text { Number of international environmental treaties } \\
\text { signed by a nation (Ecolex, 2019) }\end{array}$ & $38.02(42.20)$ & $0-269$ \\
\hline Population growth & $\begin{array}{l}\text { Annual growth of population (\% of total } \\
\text { population (World Bank, 2019) }\end{array}$ & $1.81(1.51)$ & $\begin{array}{l}-4.65- \\
16.17 \\
\end{array}$ \\
\hline Trade (\% of GDP) & $\begin{array}{l}\text { Total value of traded goods (\% of GDP) (World } \\
\text { Bank, 2019) }\end{array}$ & $77.42(48.35)$ & $\begin{array}{l}.02- \\
422.33 \\
\end{array}$ \\
\hline Debt service (\% of GNI) & $\begin{array}{l}\text { Total value of debt repayment to foreign } \\
\text { entities (\% of GNI) (World Bank, 2019) }\end{array}$ & $4.46(5.78)$ & $0-107.47$ \\
\hline Democracy & $\begin{array}{l}\text { Index measuring political rights and civil } \\
\text { liberties (Freedom House, 2018) }\end{array}$ & $3.73(2.04)$ & $1-7$ \\
\hline
\end{tabular}

Table 1: Descriptive statistics and definitions. Unlogged values for mean, standard deviation, and range are given for all logged variables for ease of interpretation. 


\section{Independent variables}

Agriculture. Cultivated land as a percent of total land area represents the pressure that agriculture puts on water resources within a nation. Since agriculture is the largest consumer of fresh water globally, it is expected that nations with more cultivated land should be associated with higher levels of water stress. However, less is known about the relationship between agriculture and water access. It is possible that more farming may be related to higher water access as agriculture may be accompanied by irrigation systems, which would make it easier to connect populations to improved water sources.

Gross domestic product per capita. Higher levels of wealth tend to bring higher standards of living, which can improve access to basic needs such as water and sanitation as well as reduce water scarcity through funding conservation programs (Anbarci et al., 2009; Bradshaw \& Schafer, 2000; Heerink et al., 2001). However, the drive for capital should also be associated with increased water stress as the rift increases. I measure gross domestic product per capita in constant 2010 US dollars (World Bank, 2019). In addition, the natural $\log$ is taken to control for the skewed distribution.

Trade. International trade is one proxy for the drive for capital. Higher levels of trade by a nation shows its embeddedness in the capitalist system. According to Metabolic Rift Theory, this commitment to capital should further exacerbate the metabolic rift, resulting in increased water stress and decreased water access. Trade is measured as the total value of traded goods as a percentage of a nation's GDP (World Bank, 2019).

International aid to the water supply and sanitation sector. International water sector aid uses data collected from AidData (2017). Using computational content analysis, these data are analyzed for human development and environmental development themes (see Hargrove, 2019). The international water sector aid data are measured in several ways. This analysis includes four measures of water sector aid. First, 'water aid count' measures the total number of aid projects ever received by a nation up to each given year. Second, 'water aid US\$' measures the total value of all water sector loans ever received by a nation up to each given year, in constant US dollars. Third, 'water aid human projects' counts the total number of aid projects received by a nation up to each given year that address human development needs such as access, health, education, and community development programs. Finally, 'water aid environmental projects' counts the total number of water sector aid projects a nation received cumulatively up to each given year that address environmental development needs such as climate change mitigation/adaptation, water scarcity, water stress, pollution, and sustainability. For example, this measure for Australia in 2000 would tell us the total number of water aid environmental projects that have been funded in Australia from 1950 to 2000. In addition, all of these variables are measured as stocks, where the data represent the cumulative total aid received up to each country year. Results for flows (total for each year individually) are substantively similar. If global water development is adequately addressing both human and environmental water needs, international aid to the water supply and sanitation sector should be associated with decreased levels of water stress and increased levels of water access.

INGOs. International non-governmental organizations (INGOs) are collected from the Yearbook of International Organizations and range from 1965 to 2015. These data report the number of INGOs that a country has at least one citizen member for (Smith and Wiest, 2005). INGOs represent the presence of civil society and indicate pressure from the citizenry on the government. Some examples of INGOs include Doctors Without Borders, Charity: Water, Save the Children, OXFAM, Amnesty International, and Greenpeace. Civil society is related to many positive human development and environmental outcomes including greater access to water and lower levels of water stress.

International environmental treaties. Data on international environmental treaties are measured as the total number of international environmental treaties signed by a nation for each given country year from 1961 to 2015 (Ecolex, 2019). International environmental treaties should be associated with lower levels of water stress, since signatory nations have an incentive to take measures to protect the sustainability of their water consumption rates. In addition, treaties should be associated with increased water access as nations who sign must ensure the health and access of their populations.

Population growth. Population growth is the annual net growth of the population as a percentage of total population (World Bank, 2019). Population growth represents the pressures put on a nation's water resources and existing infrastructure by an increasing population. It is often considered one of the primary drivers of 
water stress globally, along with agriculture. More people place increased pressure on existing water infrastructure, possibly decreasing the level of water access in nations with high growth.

Debt service. Debt service is measured as the total value of all foreign debt payments made by the state as a percentage of GDP (World Bank, 2019). The higher the burden of debt is in a nation, the less able they will be at addressing water issues within their borders, since they will have less resources to spend on public infrastructure and sustainability efforts. Debt service should be associated with greater water stress and less water access.

Female secondary school enrollment. Female secondary school enrollment is the share of total students enrolled in secondary education that are female. Female secondary school enrollment has been shown to have a strong association with access to improved water facilities (Hargrove, 2019; WHO, 2016). Since women are largely in charge of water collection in low- and middle-income nations, the assumption is that educated women are much more likely to demand and work for improved water connections than their male counterparts (Sommer and Fallon, 2020). Less research has been done on the relationship between female secondary school enrollment and water stress.

Democracy. Democracy is measured as the average level of political rights and civil liberties within a nation (Freedom House, 2018). Democratic nations are obligated to be accountable to the needs and demands of their populations (Shandra, 2007). Populations without access to water and those that experience water stress regularly will demand solutions from their governments. Higher levels of accountability represented by political rights and civil liberties should result in nations with lower levels of water stress and higher levels of water access.

\section{Findings}

Table 2 and Table 3 present two-way fixed effects estimates with robust standard errors of access to water and water stress respectively. All model specifications are identical except water sector aid. Models 2.1 and 3.1 include a water sector aid project count, Models 2.2 and 3.2 include water sector aid in US\$, Models 2.3 and 3.3 include water sector aid human development projects, and Models 2.4 and 3.4 include water sector aid environmental projects. All water aid variables are controlled for in separate models due to possible issues with multicollinearity. The first number for each variable is the unstandardized regression coefficient, the second number is the standardized coefficient, and the third in parentheses is the robust standard error.

\begin{tabular}{|lcccc|}
\hline & \multicolumn{5}{c|}{ Water Access } \\
Independent Variables & Model 2.1 & Model 2.2 & Model 2.3 & Model 2.4 \\
\cline { 2 - 5 } Agriculture & $.294^{* * *}$ & $.368^{* * *}$ & $.293^{* * *}$ & $.321^{* * *}$ \\
& .255 & .319 & .254 & .278 \\
Water Aid Count (stock) & $(.089)$ & $(.098)$ & $(.089)$ & $(.092)$ \\
& $.013^{* * *}$ & & \\
Water Aid US\$ (stock) & .086 & & \\
& $(.003)$ & & \\
& & $.263^{*}$ & \\
& & .032 & \\
& & &
\end{tabular}




\begin{tabular}{|c|c|c|c|c|}
\hline Water Aid Human (stock) & & \multicolumn{3}{|c|}{$\begin{array}{c}.014 * * * * \\
.086 \\
(.003)\end{array}$} \\
\hline Water Aid Environment (stock) & & & & $\begin{array}{c}.037 * * * \\
.070 \\
(.008)\end{array}$ \\
\hline GDP per capita (natural log) & $\begin{array}{c}1.111 \\
.106 \\
(.748)\end{array}$ & $\begin{array}{c}2.057 * * \\
.197 \\
(.768)\end{array}$ & $\begin{array}{c}1.117 \\
.107 \\
(.747)\end{array}$ & $\begin{array}{c}1.218 \\
.116 \\
(.757)\end{array}$ \\
\hline Secondary Female Education & $\begin{array}{c}.419 * * * \\
.196 \\
(.099)\end{array}$ & $\begin{array}{c}.554^{* * *} \\
.260 \\
(.111)\end{array}$ & $\begin{array}{c}.418^{* * *} \\
.196 \\
(.099)\end{array}$ & $\begin{array}{c}.488^{* * *} \\
.229 \\
(.103)\end{array}$ \\
\hline Environmental Treaty Ratification & $\begin{array}{c}-.051 * * \\
-.121 \\
(.021)\end{array}$ & $\begin{array}{c}-.074 * * * \\
.174 \\
(.021)\end{array}$ & $\begin{array}{c}-.051 * * \\
-.121 \\
(.021)\end{array}$ & $\begin{array}{c}-.059 * * \\
-.138 \\
(.020)\end{array}$ \\
\hline Population Growth & $\begin{array}{l}-.181 \\
-.015 \\
(.177)\end{array}$ & $\begin{array}{l}-.262 \\
-.022 \\
(.193)\end{array}$ & $\begin{array}{l}-.182 \\
-.015 \\
(.177)\end{array}$ & $\begin{array}{l}-.179 \\
-.015 \\
(.181)\end{array}$ \\
\hline Trade (\% of GDP) & $\begin{array}{l}-.003 \\
-.007 \\
(.009)\end{array}$ & $\begin{array}{c}.001 \\
.003 \\
(.010)\end{array}$ & $\begin{array}{l}-.003 \\
-.007 \\
(.009)\end{array}$ & $\begin{array}{c}.001 \\
-.001 \\
(.009)\end{array}$ \\
\hline Debt Service (\% GNI) & $\begin{array}{c}.013 \\
.008 \\
(.012)\end{array}$ & $\begin{array}{c}.016 \\
.010 \\
(.013)\end{array}$ & $\begin{array}{c}.013 \\
.008 \\
(.012)\end{array}$ & $\begin{array}{c}.015 \\
.009 \\
(.013)\end{array}$ \\
\hline Democracy & $\begin{array}{c}.621 * \\
.071 \\
(.273)\end{array}$ & $\begin{array}{c}.704^{* *} \\
.080 \\
(.274)\end{array}$ & $\begin{array}{c}.621 * \\
.071 \\
(.273)\end{array}$ & $\begin{array}{c}.631 * \\
.072 \\
(.269)\end{array}$ \\
\hline Constant & $51.747 * * *$ & $37.743 * * *$ & $51.757 * * *$ & $47.267 * * *$ \\
\hline Within R-Square & .667 & 628 & .667 & .654 \\
\hline Number of Observations & 841 & 841 & 841 & 841 \\
\hline Number of Countries & 176 & 176 & 176 & 176 \\
\hline
\end{tabular}

Table 2: Two-Way Fixed Effects estimates for water access, 1990-2015. Notes: a) * indicates p $<.05$, ** indicates $\mathrm{p}<.01$, and $* * *$ indicates $\mathrm{p}<.001$ for a one-tailed test. b) The first number is the unstandardized coefficient, the second is the standardized beta, and the robust standard error is in parentheses. 


\begin{tabular}{|c|c|c|c|c|}
\hline & \multicolumn{4}{|c|}{ Water Stress } \\
\hline & Model 3.1 & Model 3.2 & Model 3.3 & Model 3.4 \\
\hline \multicolumn{5}{|l|}{ Independent Variables } \\
\hline \multirow[t]{3}{*}{ Agriculture } & $.021 *$ & $.022 *$ & $.021 *$ & $.021 *$ \\
\hline & .163 & .173 & .163 & .165 \\
\hline & $(.010)$ & $(.010)$ & $(.010)$ & $(.010)$ \\
\hline \multirow[t]{3}{*}{ Water Aid Count (stock) } & -.001 & & & \\
\hline & -.008 & & & \\
\hline & $(.001)$ & & & \\
\hline \multirow[t]{3}{*}{ Water Aid USD (stock) } & & $-.018^{*}$ & & \\
\hline & & -.020 & & \\
\hline & & $(.010)$ & & \\
\hline \multirow[t]{3}{*}{ Water Aid Human (stock) } & & & -.001 & \\
\hline & & & -.008 & \\
\hline & & & $(.001)$ & \\
\hline \multirow[t]{3}{*}{ Water Aid Environment (stock) } & & & & -.001 \\
\hline & & & & -.010 \\
\hline & & & & $(.001)$ \\
\hline \multirow[t]{3}{*}{ GDP per capita (ln) } & -.020 & -.001 & -.020 & -.011 \\
\hline & -.017 & -.001 & -.017 & -.010 \\
\hline & $(.056)$ & $(.058)$ & $(.056)$ & $(.057)$ \\
\hline \multirow[t]{3}{*}{ Secondary Female Education } & .014 & $.017^{*}$ & .014 & .014 \\
\hline & .057 & .070 & .057 & .060 \\
\hline & $(.009)$ & $(.009)$ & $(.009)$ & $(.002)$ \\
\hline \multirow[t]{3}{*}{ Environmental Treaty Ratification } & $-.011 * * *$ & $-.011 * * *$ & $-.011^{* * *}$ & $-.011 * * *$ \\
\hline & -.233 & -.236 & -.233 & -.236 \\
\hline & $(.002)$ & $(.002)$ & $(.002)$ & $(.002)$ \\
\hline \multirow[t]{3}{*}{ Population Growth } & .006 & .004 & .006 & .005 \\
\hline & .005 & .003 & .005 & .004 \\
\hline & $(.022)$ & $(.022)$ & $(.022)$ & $(.022)$ \\
\hline \multirow[t]{3}{*}{ Trade (\% of GDP) } & -.001 & -.001 & -.001 & -.001 \\
\hline & -.006 & -.003 & -.006 & -.006 \\
\hline & $(.001)$ & $(.001)$ & $(.001)$ & $(.001)$ \\
\hline \multirow[t]{3}{*}{ Debt Service (\% GNI) } & .002 & .002 & .002 & .002 \\
\hline & .013 & .013 & .013 & .013 \\
\hline & $(.002)$ & $(.002)$ & $(.002)$ & $(.002)$ \\
\hline \multirow[t]{3}{*}{ Democracy } & -.024 & -.027 & -.024 & -.025 \\
\hline & -.025 & -.028 & -.025 & -.025 \\
\hline & $(.028)$ & $(.028)$ & $(.028)$ & $(.028)$ \\
\hline Constant & .861 & .570 & .863 & .767 \\
\hline
\end{tabular}




\begin{tabular}{|lllll|} 
Within R-Square & .373 & .378 & .373 & .374 \\
Number of Observations & 517 & 517 & 517 & 517 \\
Number of Countries & 165 & 165 & 165 & 165 \\
\hline
\end{tabular}

Table 3: Two-way Fixed Effects estimates for water stress, 1970 - 2015. Notes: a) * indicates p $<.05$, ** indicates $\mathrm{p}<.01$, and $* * *$ indicates $\mathrm{p}<.001$ for a one-tailed test. b) The first number is the unstandardized coefficient, the second is the standardized beta, and the robust standard error is in parentheses.

Table 2 shows the estimates for access to water and Table 3 displays the water stress models. Results are consistent across model specifications, with the exceptions of GDP and female secondary education in model 3.2. I will now discuss the findings. First, agriculture is significantly related to higher levels of access to water. For every $1 \%$ increase in agriculture as a percentage of land area, there is a .29-.37\% increase in water access. This increase may be due to nations with agricultural land cover also having more irrigation infrastructure, allowing easier connection to populations. On the other hand, agriculture is significantly associated with higher levels of water stress. This is unsurprising as agriculture makes up 92\% of the blue water footprint (Hoekstra et al. 2012). Agriculture has a much larger effect on water stress than water access, with each $1 \%$ increase in agriculture as a percentage of total land area associated with a $2.1 \%$ increase in water stress. The metabolic rift generated by large-scale agriculture as a percentage of total land area and the depletion of water sources associated with it is leaving an indelible mark on the future of our water resources. Without a change in the level of water usage currently utilized by agriculture (possibly through drip agriculture and less water hungry crops), more and more nations will experience water stress more often.

Next, all measures of water aid reach levels of statistical significance in the water access models, indicating that higher levels of water sector aid over time is related to increased levels of access to water. These projects have a cumulative effect, whereby the more aid a nation has received over time the higher their level of water access. This shows that water sector aid is actually helping nations connect their populations to improved water sources, at least partially. However, the small coefficients may signal that aid has been inefficient, with new projects only marginally increasing access. However, water sector aid fails to reach significance in all the water stress models, except for model 3.2. The negative and statistically significant coefficient of water aid US\$ stocks in model 3.2 suggests that more money sent to the water sector decreases water stress, while more projects do not have a significant impact. However, since the results are not consistent across models, it is unclear what this relationship might look like. While theoretically, water sector aid should be associated with decreased water stress, Hargrove (2019) finds that less than a third of water sector aid projects address environmental issues and many of these do not consider the complex issues of water stress and scarcity. Therefore, perhaps it is unsurprising that water sector aid has been ineffective at decreasing levels of water stress globally. Based on these findings, I believe an evaluation of the effectiveness and outcomes of past water sector projects is necessary to understand what types of projects are most successful in connecting populations to water sources and combating water stress. This information will allow funders to invest in only projects with proven effectiveness that may begin to heal the rift in the water cycle.

Secondary female education is a strong predictor of increased water access. This aligns with previous research that states that female education is one of the most important determinants of water access in low- and middle-income nations. In these models for each $1 \%$ increase in female enrollment, as a percentage of total enrollment, there is a .42-.55\% increase in access to water. GDP per capita fails to reach levels of significance in any of the models with the exception of model 3.2. These results suggest that the effect of GDP found in previous analyses may be explained by other factors in a nation such as female education or democracy. This shows that water stress is an issue that effects all nations. Additionally, it may suggest that rich nations are not utilizing their wealth effectively to combat the looming problem of increasing water stress. Furthermore, results from model 3 indicate that female secondary education is associated with higher levels of water stress. This 
finding is not consistent across model specifications but may be due to education relieving women from being the main collectors of water, who are thought to preserve water due to this proximity. However, it is more likely the case that female education is a sign that the society is investing in welfare, thus creating more access as observed in the access to water results in Table 2, creating a drain on water resources.

Moving on to the effect of global governance. Environmental treaty ratification is consistently associated with decreased levels of access to water and decreased water stress. Each additional environmental treaty a nation ratifies is associated with a decrease in water access by $\sim .05 \%$ and decreases water stress by $\sim 1.1 \%$. Additionally, environmental treaties have the largest unstandardized coefficients in the water stress models, indicating that they have a very large effect on reducing water stress within nations. These findings suggest that global governance does indeed influence these particular global ecological patterns. In addition to the effect of global governance, I also controlled for the effect of civil society in supplemental models (not included in the main findings due to high levels of multicollinearity with environmental treaty ratifications). INGOs are significantly associated with slightly lower levels of water access. For each additional INGO with at least one citizen member, a nation has .02\% lower access to water. This is surprising as many INGOs have environmental aims and human rights agendas. Furthermore, turning to the findings for water stress, I find that the work of INGOs are related to significantly lower levels of water stress. Each additional INGO in a nation is associated with a $.03 \%$ decrease in water stress. These divergent results for both global governance and civil society demonstrate that efforts around the world can have unintended negative consequences when issues are not tackled holistically. These differential effects highlight a rift in the social-ecological metabolism in the water cycle. Future work by INGOs and global governance should seek solutions that fight both stress and access problems.

Contrary to expectations, population growth is not associated with water access or water stress. This suggests that water access and water stress are social and political issues, not population capacity issues. It also suggests that household consumption of water may not be an important driver of water stress. The increases in water withdrawal from a growing population are nowhere near the levels of withdrawals for large scale agriculture. Trade and debt service fail to reach levels of significance in any models. This is surprising as these variables represent the role of capital and debt within a nation. Theoretically, we would expect that nations with higher levels of trade would increase the metabolic rift in the water cycle. However, I find that other factors are more important when predicting access and stress.

Finally, democracy is associated with higher levels of water access, but does not have a significant association with water stress. For each 1-point increase in political and civil liberties there is an associated $.65 \%$ increase in access levels. These findings suggest that the responsibility to respond to the demands of populations is associated with better water justice and possibly with better functioning of the human-water cycle metabolism. However, there is a lack of influence of democratic political systems on water stress, and there are still many democracies that face serious water stress issues which will only increase as the metabolic rift persists.

\section{Discussion}

I began by discussing how the theory of metabolic rift argues that processes resulting from capitalism often leads to the extraction of more resources from ecological sources than are returned. I aimed to extend the theory of metabolic rift by focusing on three main goals. 1) to understand how human interactions with fresh water sources generate change in water access and water stress, 2) to examine how solutions to the water crisis may have differing and unintended consequences on related water issues, and 3) to reveal the ecological consequences of ongoing capitalist and international development processes in relation to our freshwater resources. From this study, there are several main findings that help extend metabolic rift theory.

First, I find that agriculture is the largest contributor to water stress, further expanding the rift in the water cycle. However, it also seems as though agricultural production is related to higher levels of access to water. This finding suggests that large scale agriculture, while able to contribute to human goals like feeding the population and connecting them to water sources, still furthers the metabolic rift due to the over-withdrawal 
of water resources. It goes without saying that we cannot get rid of agriculture. However, it may be helpful to reform water intensive agriculture practices and decrease the portion of food that is wasted annually.

Second, I find that water sector aid, which should be a solution to the growing rift in the water cycle, has positive effects, though small, on access to water and a slight negative impact on water stress (only in terms of value of water aid received by a nation, not in terms of number of projects). Thus, while the solution to the rift in the water cycle through water sector aid may not be having negative consequences on water stress, it is also not helping very much, without challenging other processes that may further increase the rift.

Why does water aid have such a small effect on access to water and water stress? Some possible explanations may be the fragmented nature of water sector aid, debt recollection clauses contingent on the receipt of water aid, the lack of assessment or evaluation of the effectiveness of these projects, and/or less than a third of projects having any environmental component (Hargrove, 2019). However, over 90\% of projects are concerned with human access to safe drinking water and health. Given this high percentage, one would expect that there would be much larger coefficients between water sector aid and water access. This small magnitude appears to indicate that water sector aid is very inefficient at meeting its stated goals-perhaps because that is not the ultimate purpose of this aid. Aid does bring people water access, but it also goes to large-scale dam projects and other activities that accelerate capital accumulation. With loan repayments, loan conditions such as the cutting of environmental spending, and profits gained from projects run by branches of corporations originating in wealthier nations, it may be that a lot of water aid is not actually about helping people. That may be a nice side effect of the perversion of the human development agenda into neoliberal business as usual.

Third, both environmental treaties and INGOs are related to slightly lower levels of access to water and to much lower levels of water stress. There is a net positive relationship here. The effects of environmental treaties, or state environmental policymaking, shows the importance of global governance in rectifying the rift in the water cycle, especially because this is a global problem. The impacts of INGOs show the importance of civil society in the water cycle because it allows local communities to voice the problems they are encountering. Additionally, INGOs are often non-profit and focused on human needs and environmental protections. Going forward, they may be increasingly important to repairing the rift. Organizations whose aim is sustainability should naturally decrease the rift, as sustainability will be leveling our withdrawals and renewal.

Fourth, democratic states are associated with higher levels of water access and lower, but not significant, levels of water stress. While these results are promising, further analyses are required to determine the full extent of democracy's impact on water resources. Theoretically, these findings may demonstrate that a nation's obligation to act on the demands of its citizens may be able to help heal the human ecological rift. However, this can only be the case if populations within democracies demand action that leads to environmental and human justice. Put differently, democracy may be a major challenger of the metabolic rift concerning the water cycle.

\section{Conclusion}

There are several policy implications that emerge from these findings. We need to halve the amount of water withdrawals used by agriculture (Postel, 2000). According to researchers, we may do so by switching to drip irrigation and other water saving technologies and phase out high yield, water-hungry genetically modified crops, by switching to drought resistant seeds with lower yield (Postel, 2000). Furthermore, we lose about 30\% of water withdrawals through leaky pipes. New flow monitoring technology can identify the locations where pressure is decreased, indicating these leaks.

However, the root of the problem is excess withdrawals, which is the result of the valuing of short-term gain over long term losses in the capitalist system. Sustainability requires that society regulates itself such that the natural metabolism of human-nature interactions can remain viable for future generations without degrading or depleting the natural resource (Weiss et al., 2017). Capitalist societies have rarely concerned themselves with sustainability, and green-washing is also common (McMichael, 2004). Far from repairing the rift, this may actually further it because it allows us to continue our consumptive lifestyle and capital gains without addressing the underlying rift in the human-nature metabolism. 
Therefore, we may need to rely on multilateral environmental treaties, civil society, and democratic institutions to shift our world to a more sustainable future. Civil society, through INGOs and local organizations can put pressure on governments and corporations to adopt new technologies, policies, and practices that will lead to a healing of the rift. To do this, these organizations need to foster cooperation between themselves and within the multilevel governance structures (local, state, national, international). In addition, more research is needed to understand the processes that will lead to a more sustainable water future. Multilateral environmental treaties can also help to heal the rift. While often not enforceable, international treaties such as the United Nations Framework Convention on Climate Change and Resolution 64/292, which guarantees all populations the human right to water, exert strong pressure on nations to comply with the resolutions in the treaties. While research on the impact of global governance through multilateral treaties on water is nascent, this analysis and Hargrove et al. (2020) have found that these treaties have a positive impact on water stress and freshwater resources.

Although this research uses the data available to its full extent, the findings are limited. Water access and water stress have high levels of variability within nations, and should be analyzed using a multilevel or subnational analysis. Unfortunately, subnational data on water stress currently only exists at the water basin level, which presents two problems. First, water basins cross national borders and second, very few explanatory variables exist at the water basin level. This makes it nearly impossible to perform a multilevel analysis comparing the determinants of access and stress with current data. In addition, the processes that lead to access and stress are complex. While the current analysis offers a good starting point for understanding the general trends associated with access and stress, future work should utilize case studies, subnational analyses, and theoretical interactions to improve our understanding of humanity's effect on the water cycle metabolism. However, I believe that the current analysis will allow future researchers to frame water issues in terms of the differential solutions needed to solve access and scarcity issues. It demonstrates the rift in the water cycle generated by capital and large-scale agriculture.

In conclusion, development and human consumption is creating an ever-widening rift in the water cycle. Solutions to the water crisis, which the World Economic Forum has listed in the top five global risks for the past seven years, should start with the understanding that the global water crisis is multifaceted, interrelated, and generated by human consumption. To begin to heal the metabolic rift in the water cycle, we must push for cooperation, a more holistic understanding of the problem, and we must only fund solutions that will not widen the rift. Without thorough evaluations and assessment of current and past solutions through policy and aid, it will be impossible to achieve this. The future of our planet's freshwater resources depends on our actions now. If we keep treating water as unlimited renewable resource, the metabolic rift will keep growing until we reach a point where healing the rift becomes impossible.

\section{References}

Ahlborg, H. \& A.J. Nightingale. (2018). Theorizing power in political ecology: The where of power in resource governance projects. Journal of Political Ecology 25, 350-425. https://doi.org/10.2458/v25i1.22804

AidData. (2017). International aid to the water supply and sanitation sector from all lenders. [Data File]. Retrieved from http://www.aiddata.org/dashboard.

Aquastat. (2020). FAO's global information system on water and agriculture. [Data File]. Retrieved from http://www.fao.org/aquastat/en/databases/.

Anbarci, N., M. Escaleras \& C.A. Register. (2009). The ill effects of public sector corruption in the water and sanitation sector. Land Economics, 85(2), 363-377.

Barlow, M. (2014). Blue future: Protecting water for people and the planet forever. The New Press.

Bernabé-Crespo, M.B., E. Gil-Meseguer \& J.M. Gomez-Espin. (2019). Desalination and water security in southeastern Spain. Journal of Political Ecology, 26, 486-499. https://doi.org/10.2458/v26i1.22911

Black, M. \& J. King. (2009). The Atlas of Water: Mapping the world's most critical resource. University of California Press. 
Bradshaw, Y.W. \& M.J. Schafer. (2000). Urbanization and development: The emergence of international nongovernmental organizations amid declining states. Sociological Perspectives, 43(1), 97-116. https://doi.org/10.2307\%2F1389784

Bryant, R.L. \& S. Bailey. (1997). Third world political ecology. Routledge.

Clark, B. \& J.B. Foster. (2009). Ecological imperialism and the global metabolic rift: Unequal exchange and the guano/nitrates trade. International Journal of Comparative Sociology. 50(3-4), 311-334. https://doi.org/10.1177\%2F0020715209105144

Clark, B. \& R. York. (2005). Carbon metabolism: Global capitalism, climate change, and the biospheric rift. Theory and Society, 34(4), 391-428.

Clausen, R. (2007). Healing the rift: Metabolic restoration in Cuban agriculture. Monthly Review, 59(1), 4052.

Clausen, R. \& B. Clark. (2005). The metabolic rift and marine ecology: An analysis of the ocean crisis within capitalist production. Organization \& Environment, 18(4), 422-444.

Ecolex. (2019). [online database]. The gateway to environmental law. IUCN, UNEP, FAO.

Foster, J.B. (1999). Marx's theory of metabolic rift: Classical foundations for environmental sociology. American Journal of Sociology, 105(2), 366-405.

Freedom House. (2018). [online database]. Political rights and civil liberties. New York, NY: Freedom House.

Galaz, V., F. Moberg, E.K. Olsson, E. Paglia \& C. Parker. (2011). Institutional and political leadership dimensions of cascading ecological crises. Public Administration, 89(2), 361-380.

Hargrove, A. (2019). Global aid in the water sector: A descriptive analysis of international development effectiveness. International Journal of Social Science Studies 7(2): $19-35$. https://doi.org/10.11114/ijsss.v7i2.3874

Hargrove, A., M. Qandeel \& J.M. Sommer. (2019). Global governance for climate justice: A cross-national analysis of $\mathrm{CO}_{2}$ emissions. Global Transitions, 1, 190-199. https://doi.org/10.1016/j.glt.2019.11.001

Healy, H. (2019). A political ecology of transdisciplinary research. Journal of Political Ecology, 26, 500-528. https://doi.org/10.2458/v26i1.23245

Heerink, N., A. Mulatu \& E. Bulte. (2001). Income inequality and the environment: Aggregation bias in environmental Kuznets curves. Ecological Economics, 38(3), 359-367.

Hoekstra, A.Y., M.M. Mekonnen, A.K. Chapagain, R.E. Mathews, \& B.D. Richter. (2012). Global monthly water scarcity: Blue water footprints versus blue water availability. PLoS One, 7(2), e32688. https://doi.org/10.1371/journal.pone.0032688

Hof, A. \& M. Blázquez-Salom. (2015). Changing tourism patterns, capital accumulation, and urban water consumption in Mallorca, Spain: A sustainability fix? Journal of Sustainable Tourism, 23(5), 770-796. https://doi.org/10.1371/journal.pone.0032688

Homer-Dixon, T., B. Walker, R. Biggs, A.S. Crépin, C. Folke, E.F. Lambin, G.D. Peterson, J. Rockstrom, M. Scheffer, W. Steffen \& M. Troell. (2015). Synchronous failure: The emerging causal architecture of global crisis. Ecology and Society, 20(3), 6. http://dx.doi.org/10.5751/ES-07681-200306

Hornborg, A. \& J. Martinez-Alier. (2016). Ecologically unequal exchange and ecological debt. Journal of Political Ecology, 23, 328-333. https://doi.org/10.2458/v23i1.20220

Jorgenson, A.K. (2016). The sociology of ecologically unequal exchange, foreign investment dependence and environmental load displacement: Summary of the literature and implications for sustainability. Journal of Political Ecology, 23, 334-349. https://doi.org/10.2458/v23i1.20221

Manzano, J.J., A. Cardesa-Salzmann, A. Pigrau \& S. Borras. (2016). Measuring environmental injustice: How ecological debt defines a radical change in the international legal system. Journal of Political Ecology, 23, 381 - 393. https://doi.org/10.2458/v23i1.20225

Mayer, A. \& W. Haas. (2016). Cumulative material flows provide indicators to quantify the ecological debt. Journal of Political Ecology, 23, 350-363. https://doi.org/10.2458/v23i1.20222 
McClintock, N. (2010). Why farm the city? Theorizing urban agriculture through a lens of metabolic rift. Cambridge Journal of Regions, Economy and Society, 3(2), 191-207.

McGee, J. \& C. Alvarez. (2016). Sustaining without changing: The metabolic rift of certified organic farming. Sustainability, 8(2), 115. https://doi.org/10.3390/su8020115

McMichael, P. (2004). Development and social change: A global perspective. Sage Publications, Inc.

McMichael, P. (2008). Agro-fuels, food security, and the metabolic rift. Kurswechsel, 3, 14-22.

Mekonnen, M.M. \& A.Y. Hoekstra. (2011). The green, blue and grey water footprint of crops and derived crop products. Hydrology and Earth System Sciences, 15, 1577-1600. https://doi.org/10.5194/hess-15-1577$\underline{2011}$

Moglia, M. (2014). Urban agriculture and related water supply: Explorations and discussion. Habitat International, 42, 273-280. https://doi.org/10.1016/j.habitatint.2014.01.008

Pacheco-Vega, R. (2019). (Re) theorizing the politics of bottled water: Water insecurity in the context of weak regulatory regimes. Water, 11(4), 658. https://doi.org/10.3390/w11040658

Pande, S. \& A. Pandit. (2018). Hydro-social metabolism: Scaling of birth rate with regional water use. Palgrave Communications, 4(1), 1-9. https://doi.org/10.1057/s41599-018-0140-6

Paulson, S. \& L. Gezon. (2005). Political ecology across spaces, scales, and social groups. Rutgers University Press.

Peet, R. \& M.J. Watts. (Eds.) (2004). Liberation ecologies: Environment, development and social movements. Routledge.

Perdikaris, C. \& I. Paschos. (2011). Aquaculture and fisheries crisis within the global crisis. Intersciencia, 36(1), 76-80.

Pimentel, D., B. Berger, D. Filiberto, M. Newton, B. Wolfe, E. Karabinakis, S. Clark, E. Poon, E. Abbett \& S. Nandagopal. (2004). Water resources: Agricultural and environmental issues. BioScience, 54(10), 909918. https://doi.org/10.1641/0006-3568(2004)054\%5b0909:WRAAEI\%5d2.0.CO;2

Postel, S.L. (2000). Entering an era of water scarcity: The challenges ahead. Ecological Applications, 10(4), 941-948.

Schneider, M. \& P. McMichael. (2010). Deepening, and repairing, the metabolic rift. The Journal of Peasant Studies, 37(3), 461-484.

Salleh, A. (2010). From metabolic rift to metabolic value: Reflections on environmental sociology and the alternative globalization movement. Organization \& Environment, 23(2), 205-219.

Sanderson, M.R. \& R.S. Frey. (2014). From desert to breadbasket...to desert again? A metabolic rift in the High Plains Aquifer. Journal of Political Ecology, 21, 516-532. https://doi.org/10.2458/v21i1.21149

Shandra, J.M. (2007). Economic dependency, repression, and deforestation: A quantitative, cross-national analysis. Sociological Inquiry, 77(4), 543-571.

Shiva, V. (2002). Water wars: Privatization, pollution, and profit. North Atlantic Books.

Smith, J. \& D. Wiest. (2005). The uneven geography of global civic society: National and global influences on transnational association. Social Forces, 84(2), 621-652.

Sommer, J.M. (2020). Global governance in forestry: A cross-national analysis. International Journal of Sustainable Development \& World Ecology, 27(6), 481-495.

Sommer, J.M. \& K.M. Fallon. (2020). The pathway to improving human and economic development: girls' secondary education, governance, and education expenditures. Social Forces, 99(1), 205-229.

Taylor, P.L. \& D.A. Sonnenfeld. (2017). Water crises and institutions: Inventing and reinventing governance in an era of uncertainty. Society \& Natural Resources, 30(4), 395-403.

Trainer, T. (2019). Entering the era of limits and scarcity: The radical implications for social theory. Journal of Political Ecology, 26, 1-18. https://doi.org/10.2458/v26i1.23057

United Nations. (2010). State of the world's children. Oxford University Press. https://www.unicef.org/reports/state-worlds-children-2010 
Warlenius, R. (2016). Linking ecological debt and ecologically unequal exchange: Stocks, flows, and unequal sink appropriation. Journal of Political Ecology 23, 364-380. https://doi.org/10.2458/v23i1.20223

Weiss, J.S., Z. Dajian, M.A. Enriquez, P.H. May, E.P. do Nascimento, W.A. Pengue \& S. Stanislav. (2017). UN environmental policy: Non-state actors, trends, and the regulatory role of the state. Journal of Political Ecology, 24, 1013-1037. https://doi.org/10.2458/v24i1.20980

WHO. (2016). Health through safe drinking water and basic sanitation. World Health Organization.

World Bank. (2019). World development indicators. [Data File]. Retrieved from http://data.worldbank.org/indicator.

World Economic Forum. (2020). The global risks report 2020. World Economic Forum. http://www3.weforum.org/docs/WEF_Global_Risk_Report_2020.pdf

York, R., E.A. Rosa \& T. Dietz. (2003). Footprints on the Earth: The environmental consequences of modernity. American Sociological Review, 68(2), 279-300. 